\title{
MEASURING THE PROGRESS TOWARDS CIRCULAR ECONOMY IN EUROPEAN UNION COUNTRIES
}

\author{
Nicolae Pintilie \\ Bucharest University of Economic Studies, Bucharest, Romania \\ pintilienicolae15@stud.ase.ro
}

\begin{abstract}
This paper aims to create an image of progress towards circular economy registered by European Union countries through specific indicators. In this way, this paper is based on the study and analysis of the 13 indicators, grouped on 4 pillars: Production and consumption, Waste management, Secondary raw materials, Competitiveness and innovation. After the presentation of the methodology, the paper develops an analysis in time and space of the selected indicators, then an analysis of the countries with their grouping on clusters, creating a map of them and highlighting the current situation of circular economy in the European Union. Moreover, the paper also presents the evolution of the countries regarding circular economy, which has a big importance taking into account that in the European Union the preoccupations for this concept is higher from one period to another. Among the most interesting results are: (1) a massive concentration of countries with problems for Waste management pillar; (2) Europe is one of the regions with the largest contribution in terms of circular economy, but the concept is developing differently from one country to another; (3) The scoreboard evolution is particularly useful in revealing the continuous actions adopted by countries in order to facilitate the conversion to circular economy. Finally, the paper presents possible limits of the research, but also future directions of its development.
\end{abstract}

Keywords: circular economy, waste management, innovation, competitiveness

DOI: https://doi.org/10.24818/beman/2021.11.1-02

\section{INTRODUCTION}

In recent years, mankind has faced a series of extraordinary weather phenomena attributed to global warming, but also with an increasing consumption of resources due to the chosen lifestyle. Considering these aspects, both in the public and in the private domain, the preoccupations for minimizing the consumption of resources and the sustainable development of the environment were accentuated, talking more and more about the identification of the forms of alternative energy, but also about the circular economy.

The circular economy is a concept that took off a few decades ago and is evolving day by day with articles and books published worldwide. From a theoretical point of view, the circular economy is a system based on reduction, reuse, recycling, waste being considered important resource. Used or damaged products 
can be repaired and reused, and if use is no longer possible, they can be recycled, resulting in other products (Economia Circulară, 2020).

The definition is important taking into account that global consumption of resources such as biomass, fossil fuels, metals and minerals is expected to double in the next 40 years, while the volume of waste will increase by about $70 \%$ by 2050 (Silpa et al., 2018; Marinescu et al., 2019). Given that half of total greenhouse gas emissions are due to the process of extracting and manipulating resources, the Green Deal initiative was launched in the European Union, mainly aimed at increasing resource efficiency, and developing competitive economies.

The circular economy can be seen as a way for the entire mass of people to give the planet (the environment) more than it receive, while maintaining resource consumption at a balanced level. Going further to the microeconomic level, the design of a framework that encourages the development of sustainable products can be seen as a roadmap, with an emphasis on new opportunities that companies would have both nationally and internationally.

A study published by the European Commission in 2018 estimates that the adoption of the circular economy in the European Union can lead to an increase in Gross Domestic Product by about $0.5 \%$ by 2030, creating around 700,000 new jobs (European Commission, 2018). Going further, taking into account that the cost of materials and raw materials at the level of companies with a production profile in the EU is about 40\% (European Commission, 2020), the adoption of the circular economy industrial level can have a direct effect on the profitability of companies, also giving them an opportunity to reduce the pressure related to resources prices fluctuations.

The transition to a circular economy is not intended to save the planet's limited resources, but is a way to reduce greenhouse gas emissions, which are harmful to both humans and other living things. In other words, the transition from the traditional economy to the circular economy is a way forward to combat global warming and achieve performance in different economic sectors, such as in the manufacturing or in the energy sector (Cicea et al., 2021).

On the other hand, the concept of circular economy has not only a macroeconomic connotation referring strictly to the economy and the production of various products, but also to the way of life of each individual, with an emphasis on the amount of waste, how to manage it. In other words, the transformation of industrial processes by reusing part of the resulting waste is only part of the circular economy, the second aspect being related to conscious and sustainable individual consumption, so we are talking about behavioral changes. 


\section{LITERATURE REVIEW}

The concept of circular economy is increasingly debated in the literature. A simple search on the Web of Science platform can easily show how in the period 2019 - 2020 appeared over 4000 publications that referred to this concept, but the rise began much earlier, at the beginning of the decade. The researchers attempts focused primarily on trying to define the concept of the circular economy, but there were also opportunities to link the circular economy to business models or new technologies (Geisdoerfer et al., 2017; Kirchherr et al., 2017; Pan et al., 2015; Tukker, 2015). However, being a concept that has a high degree of novelty, it is not known with certainty what is the impact on the environment or the population on the transition from traditional to circular economy, there are multiple questions at the macro level (national, multinational, global-scale) (Wiebe et al., 2019; McDowall et al., 2017).

The circular economy targets a multitude of activities that take place in society, which creates difficulties in reaching a consensus among researchers regarding the interpretation of this concept (Grafström \& Aasma, 2021). The basic feature of the circular economy, which distinguishes this concept from other attempts to reduce energy consumption and consumables, is the holistic approach to raw materials, energy, waste, elements that are found in all activities of society (Bonciu, 2014; Cicea et al., 2019).

The circular economy is a new economic system that brings into question concepts such as reduction, reuse, recycling, recovery (Kristensen \& Mosgaard, 2020). This concept has its roots in the old schools of thought such as Industrial Ecology (Graedel, 1994; Lifset \& Graedel, 2002), Biomimicry (Benyus, 1997), Natural Capitalism (Lovins et al., 1999), Cradle-to-Cradle (McDonough \& Braungart, 2002), Performance Economy (Stahel, 2010), although there is an impression that this concept has recently appeared on researchers radar.

As specified by Gregson et al. (2015), the central idea of the circular economy is to extend the lifespan of products, materials, and resources. In this way, the limited resources of the planet are used in systems similar to some loops, the direct effects being the reduction of pollution by reducing waste and economic growth by increasing competitiveness (Winans et al., 2017; Marinescu \& Cicea, 2015).

The concept of circular economy has taken over in the last decade, being treated appropriately both in the literature and in the business sector (Barros et al., 2021). Of all the stakeholders, a separate organization that has taken steps to transition from the traditional economy to the circular economy is the Ellen MacArthur Foundation, an organization that presents the basics of circularity to both the public and private sectors. Given the fact that many companies consider the circular economy risky and difficult in terms of costs (Cristoni \& Tonelli, 2018), the existence of organizations that facilitate the understanding of the circular economy is well welcome. According to Ellen MacArthur Foundation (2015), the circular economy is not different from an industrial economy, but there are some other features involved such as the 
intention and design to change the way of thinking. Taking this affirmation into account, we can say that the conversion to a circular economy for the world industry does not mean reducing the means of production or limiting production, but rather the reconfiguration of production processes taking into account aspects related to environmental protection.

From a geographical point of view, the concept of circular economy has evolved differently, being influenced by the cultural, social and political particularities of each country. Germany introduced the concept of circular economy into environmental policy in the early 1990s, focusing mainly on the use of resources and raw materials to have sustainable economic growth (Geng \& Doberstein, 2008). In the late 1990s, an eco-industrial park model was promoted in China, while in the mid-2000s other measures on waste management were adopted at the level of both companies and various consumer groups (Sakai et al., 2011). Moreover, also in the Chinese space, the circular economy is seen as that mechanism that allows the development of new products, new technologies, the improvement of production equipment and industrial management (Yuan et al., 2006). Continuing with Asian continent, in Korea or Japan, on the other hand, the main aim is to increase consumer responsibility for raw materials and waste through circular economy initiatives (Prendeville \& Sherry, 2014).

The circular economy has also developed in the European space, being applied in countries such as the UK, Denmark, Switzerland or Portugal, mainly for waste management (Costa et al., 2010). In fact, the European Commission is very interested in the concept of circular economy and has been fighting for several years with the effort to facilitate the transition to a more competitive, resource-efficient, low-carbon and sustainable economy. In this spirit, at European level there are some institutions such as Scottish Institute for Remanufacture (Great Britain) and also Institut de l'Economie Circulaire (France) whose purpose is to provide assistance to industrial actors wishing to adopt this concept in their production and supply chains (Suzanne et al., 2020).

In North America and Europe, large corporations seek to implement the circular economy in programs aimed at reuse, reduction, recycling, and also pay attention to the life cycle of products (Unilever, 2021). In Serbia, the existing potential and the benefits that the circular economy would have on society are also investigated (llic \& Nikolic, 2016).

\section{MATERIALS AND METHODOLOGY}

In order to ensure the methodological transparency of this analysis focused on the most important indicators related to circular economy, the author applied a systematic review process in close accordance with other publications of this type (Cicea et al., 2019; Gora, 2019; The European House Ambrosetti \& Enel, 2020). 
The first step of this article was to define the problem that would be studied, that is "Which are the best performing countries of the European Union taking into account the circular economy criteria"? After establishing the purpose of the study, the next step was to find the indicators used in order to monitor the progress towards circular economy. For this purpose, Eurostat circular economy indicators database was chosen and used, my arguments being the compatibility with the analysis goal, but also the exhaustiveness of the data set.

After choosing the database, in order to assure the unanimity of the approach, the third step was to identify the last period which contains updated values for all set of indicators. In this way, only 2018 had updated values for all the involved indicators. As a result, the analysis was made using 13 indicators, grouped in 4 categories.

In order to measure the current situation of circular economy activities in European Union countries and also the progress made from one period to another, the below steps were followed:

- We downloaded from Eurostat database the values for circular economy indicators for 2014 and 2018;

- Each indicator was analyzed separately. In this sense, in order to see the position of the European Union countries according to each indicator, the Rank function in Microsoft Excel was applied;

- The position occupied by each country represents the score obtained at the level of each indicator (a low score means a high performance in terms of applying the principles of the circular economy at the country level);

- After determining the scores obtained by the European Union countries for each indicator, the next step was to sum up all the scores (the lowest score means the highest position in terms of the transition to the circular economy);

- In order to measure the progress made by the European Union countries, the same steps were taken for 2014;

- The results obtained both at a general level and at a particular level for each category allowed the division of countries into 4 clusters: high level, good level, medium level, low level.

Finally, the analysis that has been performed followed the stated methodology:

- STAGE 1 - Cluster country analysis for each pillar - on one hand, through this analysis the author wants to observe for each country which are the pillars with bad evolution and which are the pillars with good evolution. On the other hand, the author wants to see the comparison between countries regarding these pillars; 
- STAGE 2 - Graphical distribution of countries - this stage is helping us to see which are the geographical areas of interest in order to implement the circular economy;

- STAGE 3 - Identifying significant clusters based on calculations - through this stage the author is trying to see the most successful countries oriented at achieving circular economy. Moreover, this analysis is very important to understand what implications there are regarding conversion to circular economy, this concept including a lot of other subdomains.

In order to be able to visualize the analysis results, the Microsoft Excel software was chosen and used.

\section{RESULTS AND DISCUSSION}

In order to assess the progress of the European Union countries regarding circular economy, the analysis has been performed for 13 indicators, grouped in 4 categories:

\section{- Production and consumption}

- In order to understand progress towards the circular economy we need to focus on the production and consumption phase. Both companies, public institution and household should decrease the amount of waste they generate. Reducing the amount of generated waste, the production has the possibility to use raw materials. In this paper the smaller the value of the indicators, the better the performance for the countries.

\section{- Waste management}

- This pillar is essential for circular economy because we can find how much recycled waste returns into economic cycle to continue creating value. This category of indicators is showing us the current status of every country regarding waste treat programs. In this paper, the bigger the value of indicators, the better the performance for the countries.

\section{- Secondary raw materials}

- The circular economy is seen like a loop. In this case, in order to close the loop, materials and products need to be place again into the economy, taking form of new materials or new products. In this way, it is not necessary to use new resources in order to produce a specific object, this action having a positive impact on environmental footprint of production and also on the security of supplies. In this paper, the bigger the value of indicators, the better the performance for the countries.

\section{- Competitiveness and innovation}

- The circular economy has a contribution on the creation of new jobs and economic growth because the innovation is the key for the transition. Through innovation, new technologies have a better design, are characterised by a smaller resource 
consumption and also the industrial processes are modified. In this regard, circular economy is closely related to other concepts, such as innovation-driven economy and knowledge-based economy (Fucec \& Marinescu, 2014). In this paper, the bigger the value of indicators, the better the performance for the countries.

It was very important for the analysis to maintain the unity in the measurement process, so in this way the author chose to use the data from 2018 period (the last period with updated values for all indicators).

All the categories explained can be seen in the Table1.

TABLE 1. THE KeY PERFORMANCE INDICATORS OF CIRCULAR ECONOMY SCOREBOARD

\begin{tabular}{|c|c|c|}
\hline Category & Indicator & Unit measure \\
\hline \multirow[t]{3}{*}{ Production and consumption } & $\begin{array}{l}\text { Generation of municipal waste } \\
\text { per capita }\end{array}$ & Kilograms per capita \\
\hline & $\begin{array}{l}\text { Generation of waste excluding } \\
\text { major mineral wastes per GDP } \\
\text { unit }\end{array}$ & Kilograms per thousand euro \\
\hline & $\begin{array}{l}\text { Generation of waste excluding } \\
\text { major mineral wastes per } \\
\text { domestic materiale consumption }\end{array}$ & Percentage \\
\hline \multirow[t]{6}{*}{ Waste management } & $\begin{array}{l}\text { Recycling rate of municipal } \\
\text { waste }\end{array}$ & Thousand tonnes \\
\hline & $\begin{array}{l}\text { Recycling rate of all waste } \\
\text { excluding major mineral waste }\end{array}$ & Percentage \\
\hline & $\begin{array}{l}\text { Recycling rate of packaging } \\
\text { waste by type of packaging }\end{array}$ & Percentage \\
\hline & Recycling rate of e-waste & Percentage \\
\hline & Recycling of biowaste & Kilograms per capita \\
\hline & $\begin{array}{l}\text { Recovery rate of construction } \\
\text { and demolition waste }\end{array}$ & Percentage \\
\hline \multirow[t]{2}{*}{ Secondary raw materials } & Circular material use rate & Percentage \\
\hline & $\begin{array}{l}\text { Trade in recyclable raw } \\
\text { materials }\end{array}$ & Tonne \\
\hline \multirow[t]{2}{*}{ Competitiveness and innovation } & $\begin{array}{l}\text { Private investments, jobs and } \\
\text { gross value added related to } \\
\text { circular economy sectors }\end{array}$ & $\begin{array}{l}\text { Value added at factor cost - } \\
\text { million euro }\end{array}$ \\
\hline & $\begin{array}{l}\text { Patents related to recycling and } \\
\text { secondary raw materials }\end{array}$ & Number \\
\hline
\end{tabular}

Source: author 
Despite the fact that we try to work as good as possible in order to have a unanimity approach, we had several limitations:

- For Recycling rate of all waste excluding major mineral waste the Eurostat data was only for the period 2014 and 2016;

- For the same indicator highlighted above there were no data for 2 countries: Greece and Latvia;

- For Patents related to recycling and secondary raw materials the Eurostat data was only for the period 2014 and 2016;

- For Trade in recyclable raw materials there were no data for United Kingdom;

- For Private investments, jobs and gross value added related to circular economy sectors there were no data for 5 countries: Czechia, Estonia, Ireland, Luxembourg and Malta.

In accordance with the phases above outlined, we will first analyse the status of the countries for the analyzed categories of indicators regarding circular economy. Thus, using the Eurostat database and Microsoft Excel software, we obtained the following status, graphically represented in Figure 1.

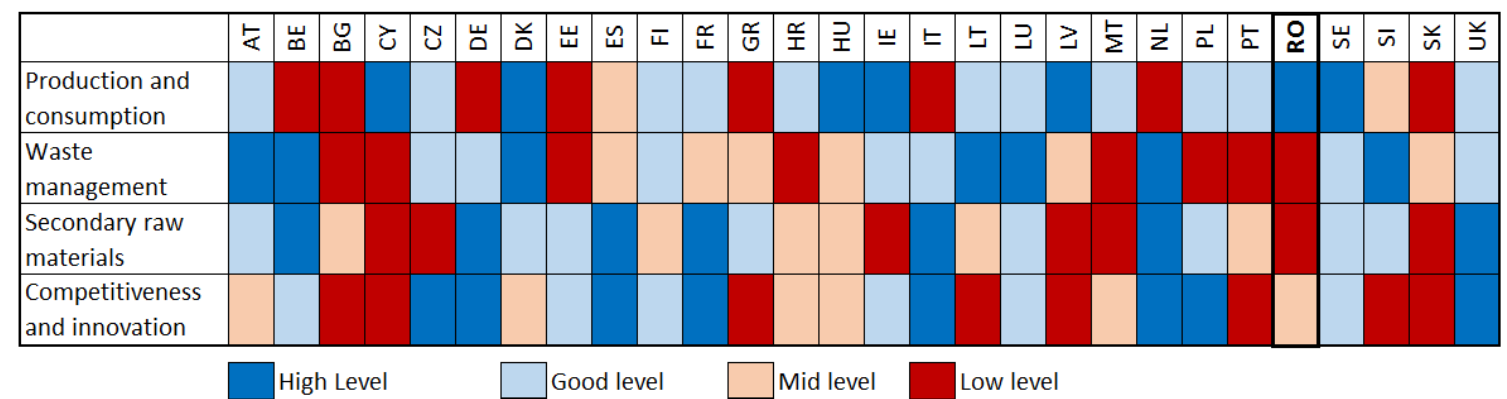

FIGURE 1. VIEW OF THE EUROPEAN COUNTRIES (EU27 + UK) IN THE CIRCULAR ECONOMY SCOREBOARD - 2018

Source: author using Microsoft Excel

As we can see from Figure 1, based on data from 2018 period, we can conclude that at the level of European Union there is a heterogenous performance in the conversion towards circular economy. Analyzing the Figure 1 we can observ that there are some countries such as Austria, Denmark, Lithuania, Sweden and United Kingdom with good positions regarding circular economy indicators, but there are also some countries such as Bulgaria, Slovakia or Cyprus with some poor situation regarding circular economy. 


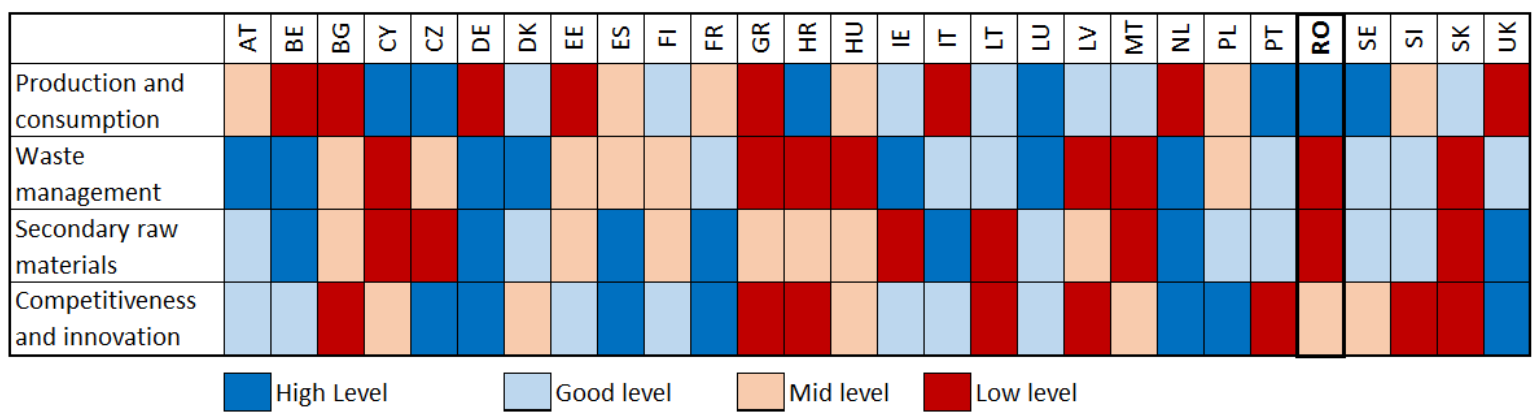

\section{FIGURE 2. VIEW OF THE EUROPEAN COUNTRIES (EU27 + UK) IN THE CIRCULAR ECONOMY SCOREBOARD - 2014 \\ Source: author using Microsoft Excel}

Looking closer at the graphical representation within Figure 1 and Figure 2, we can easily observ that there are several countries with changed position towards the categories involved. Austria passed from Good level for Competitiveness and innovation in 2014 to Mid level in 2018, being a sign that other countries gain position for this particular point in comparison with Austria. In this way, we can mention Ireland which passed from Mid level in 2014 to Good level in 2018, or Italy which passed from Good Level in 2018 to High level in 2018. So, compared to 5 years ago, these countries show significant improvement regarding Competitiveness and Innovation pillar.

In the particular case of Romania, there are no changes between years as far as the circular economy indicators concern. There is a High level for Romania for Production and consumption category, being the first 7 countries of the European Union, but there are also improvements needed for Waste management and Secondary raw materials categories.

In order to see the level the performance of the European Union countries on the topic of circular economy, we need to pay attention to the general circular economy scoreboard (Table 2) and the graphic representation of the countries (Figure 3).

TABLE 2. CIRCULAR ECONOMY SCOREBOARD - 2018

\begin{tabular}{|l|l|r|r|r|}
\hline Country & Indicator & Total Score & \multicolumn{1}{l|}{ Ranking } & Cluster \\
\hline Netherlands & NL & 102 & 1 \\
\hline United Kingdom & UK & 118 & 2 \\
\hline Germany (until 1990 former territory of the FRG) & DE & 125 & 3 \\
\hline Belgium & BE & 126 & 4 \\
\hline Denmark & DK & 126 & 4 \\
\hline Luxembourg & LU & 129 & 6 \\
\hline Austria & AT & 135 & 7 \\
\hline
\end{tabular}


Pintilie, N.

MEASURING THE PROGRESS TOWARDS CIRCULAR ECONOMY IN EUROPEAN UNION COUNTRIES

\begin{tabular}{|c|c|c|c|}
\hline Italy & IT & 136 & 8 \\
\hline Sweden & SE & 146 & 9 \\
\hline France & $\mathrm{FR}$ & 155 & 10 \\
\hline Spain & ES & 161 & 11 \\
\hline Ireland & $\mathrm{IE}$ & 169 & 12 \\
\hline Slovenia & SI & 170 & 13 \\
\hline Czechia & $C Z$ & 172 & 14 \\
\hline Hungary & $\mathrm{HU}$ & 182 & 15 \\
\hline Finland & $\mathrm{FI}$ & 182 & 15 \\
\hline Lithuania & LT & 185 & 17 \\
\hline Poland & PL & 190 & 18 \\
\hline Latvia & LV & 192 & 19 \\
\hline Estonia & $\mathrm{EE}$ & 214 & 20 \\
\hline Croatia & $H R$ & 215 & 21 \\
\hline Portugal & PT & 216 & 22 \\
\hline Greece & $\mathrm{GR}$ & 226 & 23 \\
\hline Slovakia & SK & 233 & 24 \\
\hline Malta & MT & 240 & 25 \\
\hline Bulgaria & BG & 257 & 26 \\
\hline Romania & RO & 258 & 27 \\
\hline Cyprus & $\mathrm{CY}$ & 259 & 28 \\
\hline
\end{tabular}

Source: author using Microsoft Excel

As the Table 2 confirms, the main source of circular economy progress is Netherlands, with the lowest total score of 102 points. On the second place, United Kingdom is behind Netherlands with 16 points, but we have to say that there are some missing data for United Kingdom which can affect the total scoreboard. At a little distance between them, Germany, Belgium and Denmark are on the 3 and 4 places, confirming that there are some pioneers in the circular economy domain.

Moving to the last countries from the table, there are particulary countries from Eastern Europe, characterized by the transition to the market economy. Romania has improved its performance over time for several indicators, but comparing with other European Union countries the values are lower and this is the reason for the position obtained in the general scoreboard. 
Looking closer at the graphical representation within Figure 3 we can observ the distribution of the countries within clusters displayed in Table 2.

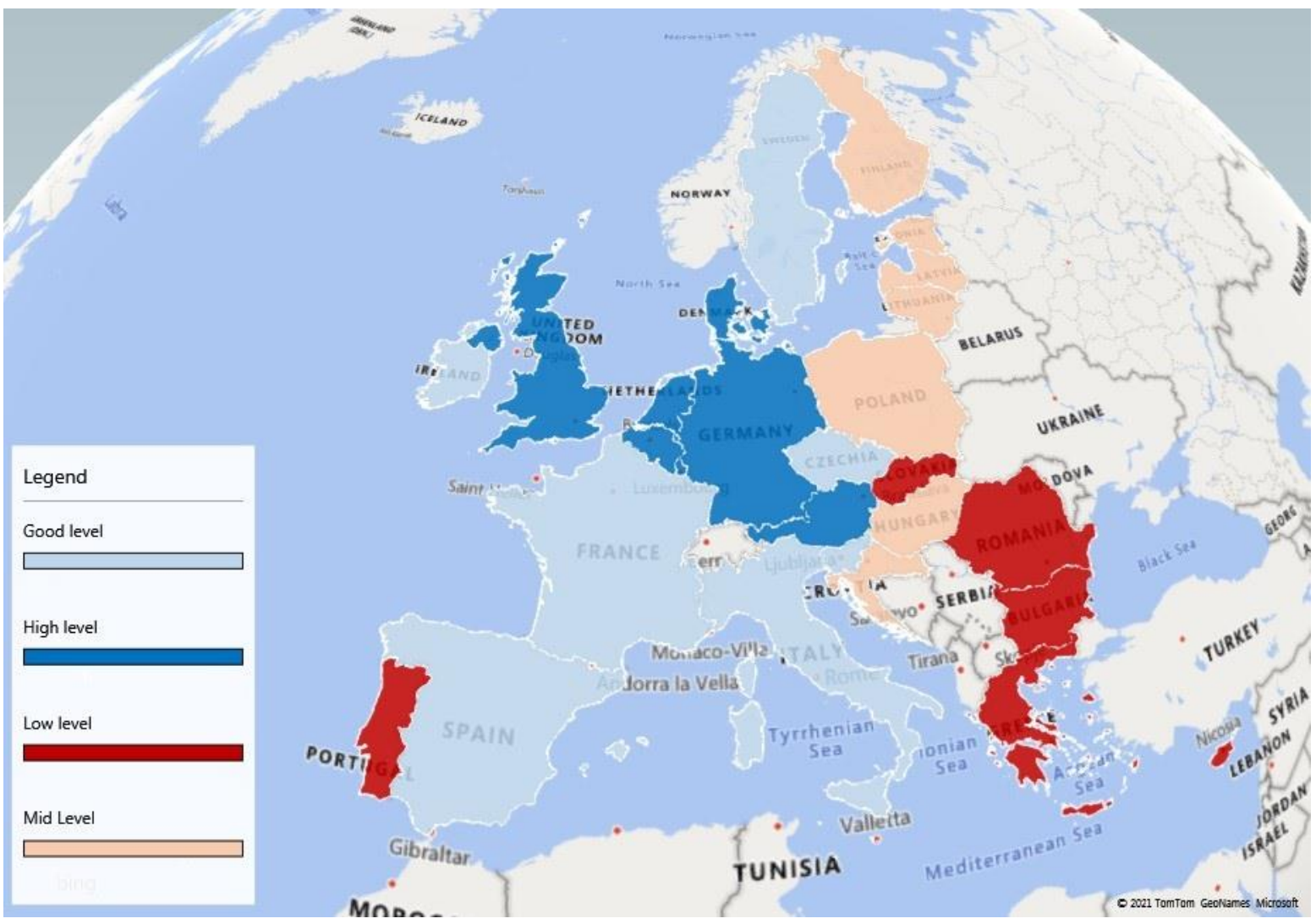

FIGURE 3. REPRESENTING THE SCOREBOARD REGARDING CIRCULAR ECONOMY INDICATORS

Source: author using Microsoft Excel

As we said before, Eastern European countries are characterized by a low level of circularity, having some difficulties to make the conversion from traditional economy to circular economy. A particular case is Portugal, but we can take into account that this country is on the edge between Low level and Mid level.

Moving forward, the most European Union countries from North-Estern Europe are placed in the Mid level, showing a gowing progress for the circularity inputs. The performers are the countries placed on the first 14 positions, which have their score lower than the European Union Average. There are countries placed in High level and Good level clusters, with a confirmed progress toward circular economy actions. 
Pintilie, N.

MEASURING THE PROGRESS TOWARDS CIRCULAR ECONOMY IN EUROPEAN UNION COUNTRIES

TABLE 3. SCOREBOARD EVOLUTION OVER THE PERIOD 2014 - 2018

\begin{tabular}{|c|c|c|c|c|c|c|c|c|}
\hline Country & Indicator & $\begin{array}{c}\text { Total } \\
\text { Score } \\
2014\end{array}$ & $\begin{array}{c}\text { Ranking } \\
2014\end{array}$ & $\begin{array}{c}\text { Cluster } \\
2014\end{array}$ & $\begin{array}{c}\text { Total } \\
\text { Score } \\
2018\end{array}$ & $\begin{array}{c}\text { Ranking } \\
2018\end{array}$ & $\begin{array}{c}\text { Cluster } \\
2018\end{array}$ & \begin{tabular}{|} 
Evolution \\
over the \\
period 2014 - \\
2018
\end{tabular} \\
\hline Hungary & $\mathrm{HU}$ & 216 & 20 & & 182 & 15 & & ค \\
\hline Greece & GR & 258 & 28 & & 226 & 23 & & ↔ \\
\hline Belgium & $\mathrm{BE}$ & 140 & 8 & & 126 & 4 & & ↔ \\
\hline United Kir & UK & 130 & 5 & & 118 & 2 & & ค \\
\hline Denmark & DK & 134 & 7 & & 126 & 4 & & ค \\
\hline Spain & ES & 170 & 14 & & 161 & 11 & & ค \\
\hline Finland & $\mathrm{FI}$ & 182 & 17 & & 182 & 15 & & ค \\
\hline Latvia & LV & 222 & 21 & & 192 & 19 & & ค \\
\hline Croatia & HR & 232 & 23 & & 215 & 21 & & 个 \\
\hline Italy & IT & 142 & 9 & & 136 & 8 & & 个 \\
\hline Lithuania & LT & 199 & 18 & & 185 & 17 & & ค \\
\hline Netherlan & NL & 101 & 1 & & 102 & 1 & & $\Rightarrow$ \\
\hline France & FR & 145 & 10 & & 155 & 10 & & $\xi$ \\
\hline Ireland & IE & 162 & 12 & & 169 & 12 & & $\xi$ \\
\hline Slovenia & SI & 169 & 13 & & 170 & 13 & & $\xi$ \\
\hline Malta & MT & 242 & 25 & & 240 & 25 & & $\xi$ \\
\hline Romania & RO & 243 & 27 & & 258 & 27 & & $\xi$ \\
\hline Germany & DE & 113 & 2 & & 125 & 3 & & $\sqrt{3}$ \\
\hline Estonia & EE & 203 & 19 & & 214 & 20 & & $\sqrt{3}$ \\
\hline Slovakia & SK & 226 & 22 & & 233 & 24 & & $\sqrt{3}$ \\
\hline Bulgaria & BG & 235 & 24 & & 257 & 26 & & $\sqrt{3}$ \\
\hline Luxembou & LU & 120 & 3 & & 129 & 6 & & $\sqrt{3}$ \\
\hline Austria & AT & 125 & 4 & & 135 & 7 & & $\sqrt{3}$ \\
\hline Sweden & SE & 133 & 6 & & 146 & 9 & & $\sqrt{3}$ \\
\hline Czechia & $\mathrm{CZ}$ & 159 & 11 & & 172 & 14 & & $\sqrt{3}$ \\
\hline Poland & PL & 177 & 15 & & 190 & 18 & & $\sqrt{3}$ \\
\hline Cyprus & $\mathrm{CY}$ & 242 & 25 & & 259 & 28 & & $\sqrt{3}$ \\
\hline Portugal & PT & 179 & 16 & & 216 & 22 & & $\sqrt{4}$ \\
\hline
\end{tabular}

Source: author using Microsoft Excel

In terms of progress regarding circular economy indicators, this was undertaken with help of Microsoft Excel software. In order to obtain valid results, we compared the rank of the countries from 2018 with the rank from 2014. The results are displayed in Table 3.

As we can see, there are 11 countries at the level of European Union which registered progress regarding the circular economy indicators. Taking this affirmation into account, the positions of these countries improved, moving from one cluster to another. There are 6 countries which managed to 
maintain the position at the level of European Union, improving the values of indicators, but not also the score in comparison with other countries.

In the last category, there are 11 countries which lost their positions occupied in 2014. It is mostly about two categories of countries included in this category:

- Countries with a high scoreboard, placed in the High level category, which they have reached a certain maturity;

- Mid and Low level countries which are in the transition regarding conversion to circular economy and had some particular issues (political, economical) in the period between 2014 and 2018.

An even more suggestive situation was generated in Microsoft Excel based on the grouping of countries taking into account the deviation between the general scoreboard and the European Union average scoreboard. This grouping is visually designed as a graph which includes each country and it is displayed in Figure 4.

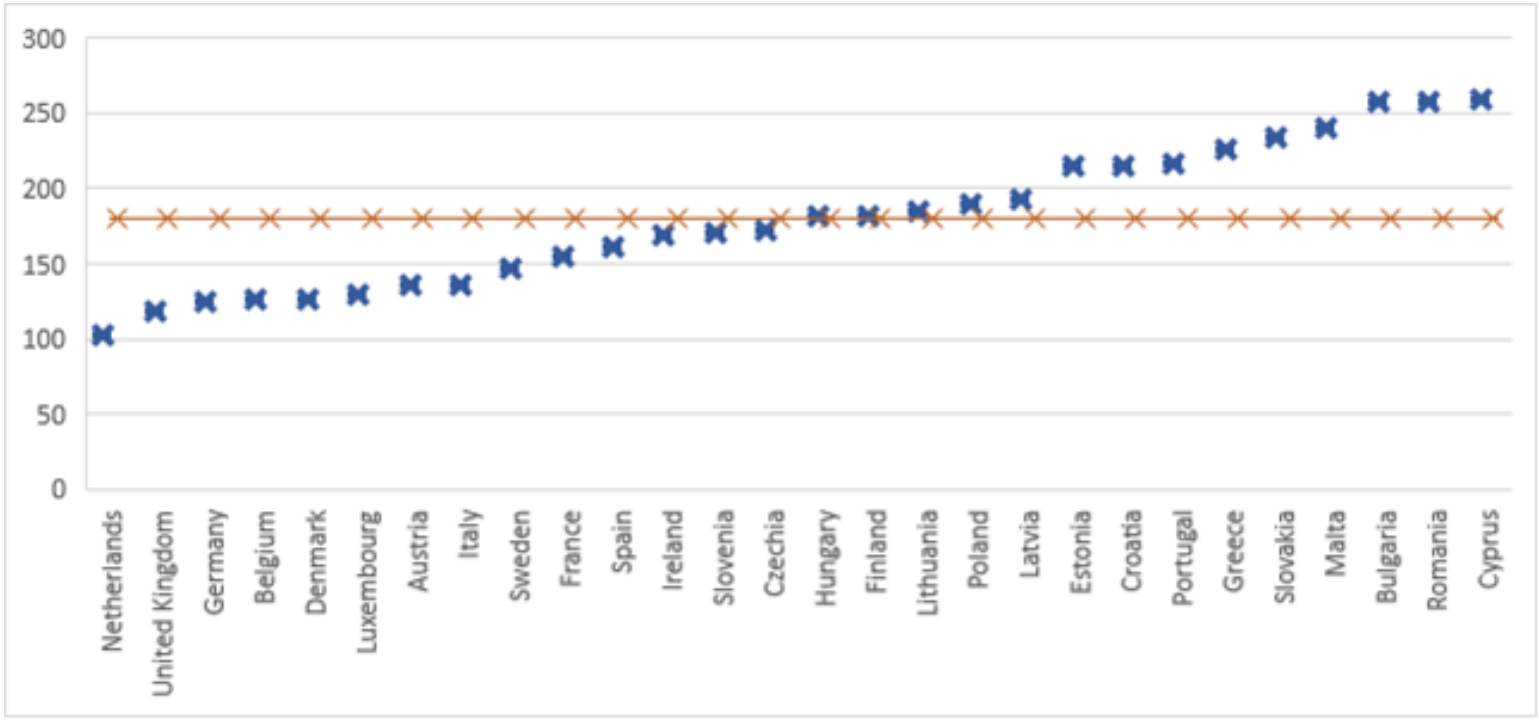

\section{FIGURE 4. COMPARISON BETWEEN THE SCORE OF THE CIRCULAR ECONOMY SCOREBOARD AND THE EUROPEAN UNION AVERAGE SCOREBOARD}

Source: author using Microsoft Excel

Looking closer at the graphical representation within Figure 4, we can observe 3 big categories of countries related to progress linked to circular economy.

As the graph confirms, the most successful countries regarding circular economy are countries with a high level of development, with a recognised history in the domain of regional and global policies with the goal of promoting environmental protection. This groupe of countries is followed by a mixed group formed by countries situated in central and northern Europe, characterized by the adoptation of several 
measures that can bring about tremendous improvements on the circular economy. The last group of countries is composed by countries situated mostly in the Eastern Europe, characterized by a long transition to market economy after the final of Cold War.

\section{CONCLUSIONS}

The current study has a contribution in understanding the situation in European Union countries, analyzing the most representative indicators of this phenomena according to Eurostat database. The general conclusion is that the European Union countries are on the right track regarding circular economy implementation, which can have a big contribution to resource efficiency.

Within this paper, the construction of the graphs has revealed salient features of circular economy. Although in collective thinking is considering that in 5 years a lot of things can change, the research shows that it is quite difficult for countries to register progress regarding circular economy in this particular time. For this point of view, Figure 1 and Figure 2 are representative because they show little difference, but we have to highlight that from the point of view of the value of indicators the situation is much better, 2018 being characterised by improvements for all the analyzed indicators.

By calculating the Circular Economy Scoreboard we are able to see which country can be associated with a pioneer in the field of circular economy, helping us to understand what measures can we adopt in order to develop in the same direction.

Taking this situation into account, a further paper can take into consideration particular measures adopted by countries which facilitate the transition to circular economy.

Taking into account Figure 3, we can say that the topic of the paper is a central one in Europe, but the development is different from one country to another. Western European countries represent the main source of the development regarding circular economy, central european countries being the most important pillar in this proccess. On the other hand, we can highlight that there are also countries from all around the European Union which are interested in the conversion to circular economy, being in the transition stage. With other words, these countries are tring to understand how to do things, how to improve their operations in order to be more and more friendly from the point of view of environment.

Even though the author explained in detail the methodology used within this paper, the study has some limitations. First of all, only Eurostat database was used in order to obtain datas. A similar analysis could be conducted using other databases, such as OECD or World Bank, which may influence the final results. Second, for some countries there was no data for some particular indicators, which can affect the general scoreboard and the final cluster. Third, the concept of circular economy is just at the 
beginning, specific issues about this concept will be in the light of researchers attention, so this may constitute a future research direction revealing ways of transition through circular economy.

\section{ACKNOWLEDGMENT}

This paper is a result of the research conducted through the 2020 - 2023 Doctoral advanced research program at The Bucharest University of Economic Studies.

\section{REFERENCES}

Barros, M. V., Salvador, R., do Prado, G. F., de Francisco, A. C., \& Piekarski, C. M. (2021). Circular Economy as a driver to sustainable businesses. Cleaner Environmental Systems, 1 - 11.

Benyus, J. (1997). Biomimicry. New York, NY: Harper Perennial.

Bonciu, F. (2014). The European Economy: From a Linear to a Circular Economy. Romanian Journal of European Affairs, 14(4), 78 - 91.

Cicea, C., Marinescu, C., Albu, C.F., \& Balan, P.D (2019). Applying Bibliometric Mapping and Clustering on Research regarding Biomass related Innovation. in Proceedings of 33rd IBIMA Conference: 1011 April 2019, (pp. 2404 - 2419). Granada, Spain.

Cicea, C., Marinescu, C., \& Pintilie, N. (2019). Smart cities using smart choices for energy: integrating modern bioenergy in consumption. Theoretical and Empirical Researches in Urban Management, 14(4), 22-34.

Cicea, C., Marinescu, C., \& Pintilie, N. (2021). New Methodological Approach for Performance Assessment in the Bioenergy Field. Energies, 14(4), 901. https://doi.org/10.3390/en14040901

Cristoni, N., \& Tonelli, M. (2018). Perceptions of Firms Participating in a Circular Economy. European Journal of Sustainable Development, 7, 105 - 118.

Costa, I., Massard, G., \& Agarwal, A. (2010). Waste management policies for industrial symbiosis development: case studies in European countries. Journal of Cleaner Production, 18(8), 815 - 822.

Economia Circulară. (n.d.). Retrieved February 17, 2021, from https://www.mmu.ac.uk/media/mmuacuk/content/documents/w2rin/5756-R4GM-IO4-Romanianv3.pdf

European Commission. (2018). Impacts of circular economy policies on the labour market. Bruxelles.

European Commission. (2020). Circular Economy Action Plan for a cleaner and more competitive Europe. Bruxelles.

Ellen MacArthur Foundation. (2015). Towards the Circular Economy: Economic and Business Rationale for an Accelerated Transition. Isle of Wight.

Fucec, A. A., \& Marinescu (Pirlogea), C. (2014). Knowledge Economies in the European Union: Romania's Position. Procedia Economics and Finance, 15, 481-489. https://doi.org/10.1016/S22125671(14)00489-4

Geisdoerfer, M., Savaget, P., Bocken , N., \& Hultink, E. (2017). The Circular Economy - a new sustainable paradigm. Journal of Cleaner Production, 143(1), 758 - 768.

Geng, Y., \& Doberstein, B. (2008). Developing the circular economy in China: Challenges and opportunities for achieving 'leapfrog development'. The International Journal of Sustainable Development and World Ecology, 15(3), 231 - 239. 
Gora, A. A. (2019). The Link Between Decision Making Process and Performance: A Bibliometric Analysis. Management and Economics Review, 4(2), 177 - 191.

Graedel, T. (1994). Industrial ecology:definition and implementation. Industrial ecology and global change, $23-41$.

Grafström, J., \& Aasma, S. (2021). Breaking circular economy barriers. Journal of Cleaner Production, 292, 1 - 14.

Gregson, N., Crang, M., Fuller, S., \& Holmes, H. (2015). Interrogating the circular economy: the moral economy of resource recovery in the EU. Economy and Society, 44, 218 - 243.

llic, M., \& Nikolic, M. (2016). Drivers for development of circular economy - a case study of Serbia. Habitat International, 191 - 200.

Kirchherr, J., Reike, D., \& Hekkert, M. (2017). Conceptualizing the circular economy: An analysis of 114 definitions. Resources, Conservation and Recycling, 127, 221 - 231.

Kristensen, H. S., \& Mosgaard, M. A. (2020). A review of micro level indicators for a circular economy moving away from the three dimensions of sustainability?. Journal of Cleaner Production, 243.

Lifset, R., \& Graedel, T. (2002). Industrial ecology: goals and definitions. A handbook of industrial ecology, $3-15$.

Lovins, A., Lovins, L., \& Kawken, P. (1999). A road map for natural capitalism. Harvard Business Review, 77(3), 58 - 145.

Marinescu, C., \& Cicea C. (2015). Measuring renewable energy influence on economic growth: Evidence from a panel of European countries. International Multidisciplinary Scientific GeoConference Surveying Geology and Mining Ecology Management (SGEM), 3(5), 407-414.

Marinescu, C., Cicea, C., \& Colesca, S. E. (2019). Tracking biofuels-innovation relationship through scientific and technological advances. Management Research and Practice, 11(2), 31-44.

McDonough, W., \& Braungart, M. (2002). Remaking the Way We Make Things: Cradle to Cradle. New York, NY: North Point Press.

McDowall, W., Geng, Y., Huang, B., Bertekova, E., Bleischwitz, R., \& Turkeli, S. (2017). Circular Economy Policies in China and Europe. Journal of Industrial Ecology, 651 - 661.

Pan, S.-Y., Du, M., Huang, I.-T., Liu, I.-H., Chang, E.-E., \& Chiang, P.-C. (2015). Strategies on implementation of waste-to-energy (WTE) supply chain for circular economy system: a review. Journal of Cleaner Production, 108, 409 - 421.

Prendeville, S., \& Sherry, J. (2014). Circular Economy: Is It Enough?. Wales: Ecodesign Centre.

Sakai, S.-i., Yoshida, H., Hirai, Y., Asari, M., Takigami, H., Takahashi, S. et al. (2011). International comparative study of $3 \mathrm{R}$ and waste management policy developments. Journal of Material Cycles and Waste Management, 13, 86 - 102.

Silpa, K., Yao, L., Bhada-Tata, P., \& Van Weerden, F. (2018). What a Waste 2.0: A Global Snapshot of Solid Waste Management to 2050. Washington: World Bank.

Stahel, W. R. (2010). The performance economy - Second edition. New York, NY: Palgrave MacMillan.

Suzanne, E., Absi, N., \& Borodin, V. (2020). Towards circular economy in production planning: Challenges and opportunities. European Journal of Operational Research, 168 - 175.

The European House Ambrosetti, Enel. (2020). Circular Economy - How to successfully manage the transition from a linear to a circular world. Fondazione Centro Studi Enel.

Tukker, A. (2015). Product services for a resource-efficient and circular economy - a review. Journal of Cleaner Production, 76 - 91. 
Unilever. (2021). Reducing our environmental impact. Retrieved February 18, 2021, from https://www.unilever.com/about/innovation/safety-and-environment/reducing-our-environmentalimpact/

Wiebe, K., Harsdorff, M., Montt, G., Simas, M., \& Wood, R. (2019). Global Circular Economy Scenario in a Multiregional Input - Output Framework. Environmental Science \& Technology, 53(11), 6362 6373.

Winans, K., Kendall, A., \& Deng, H. (2017). The history and current applications of the circular economy concept. Renewable and Sustainable Energy Reviews, 68, 825 - 833.

Yuan, Z., Bi, J., \& Moriguchi, Y. (2006). The Circular Economy: A New Development Strategy in China. Journal of Industrial Ecology, 10(1-2), 4 - 8. 